\title{
高齢者䅡部脊骾症に対する脊柱管拡大術の検討
}

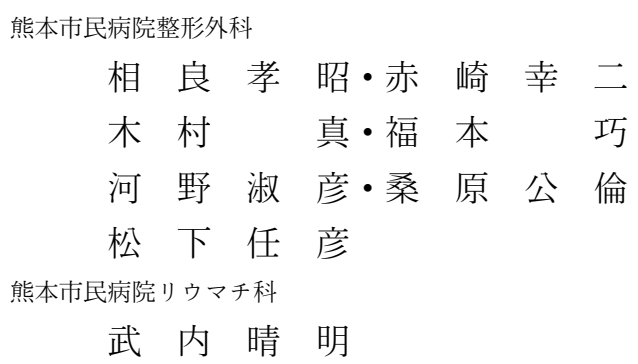

\section{Results of Laminoplasty for Cervical Spondylotic Myelopathy in Elderly Patients}

\author{
Taka-aki Sagara, Koji Akasaki, Makoto Kimura, Takumi Fukumoto, \\ Yoshihiko Kono, Korin Kuwahara, and Nobuhiko Matsushita \\ Department of Orthopaedic Surgery, Kumamoto City Hospital, Kumamoto, Japan \\ Haruaki Takeuchi \\ Department of Rheumatology, Kumamoto City Hospital, Kumamoto, Japan
}

\begin{abstract}
We studied elderly patients over 70 years old who underwent laminoplasty for cervical spondylotic myelopathy. Operations were performed on 21 patients over 70 years old at the time of operation from 1995 at the Kumamoto City Hospital. These patients were reviewed and compared with patients below 69 years old in this study. Clinical results were evaluated by the Japanese Orthopaedic Association scoring system. The operative results of patients over 70 were not significantly different from those of patients below 69. But we found that the recovery of the lower motor function of elderly patients was apparently worse than that of younger patients statistically.
\end{abstract}

Key words : cervical spondylotic myelopathy (頚部脊䯣症), elderly patient (高齢者), laminoplasty （脊柱管拡大術）

は じめに

我が国における高齢化の進行とともに高齢者の脊椎 手術も増えている。そこで今回我々は，高齢者の頚部 脊髄症に対して脊柱管拡大術を施行した症例を調査検 討したので報告する。

\section{対象および方法}

1995 年 4 月以降頚部脊髄症の診断で脊柱管拡大術 を施行し，6 ケ月以上経過観察が可能であった 70 歳
以上の高齢者 21 例を対象症例とした。また同時期に 手術した 69 歳以下の非高齢者 15 例を比較対照群とし た。手術時年齢は高齢者群 70 歳 84 歳（平均 73.5 歳), 非高齢者群 44 歳 69 歳 (平均 62.5 歳), 男女 比はそれぞれ男性 12 例女性 9 例, 男性 9 例女性 6 例 であった。また平均経過観察期間は 28.9 ケ月と 33.7 ケ月であった。これらの症例について, 術前罹病期間, 手術時間・出血量, 術前及び最終調查時の JOA score, 平林法による改善率, 術前後の合併症などに ついて検討を加えた。統計学的には Mann-Whitney 

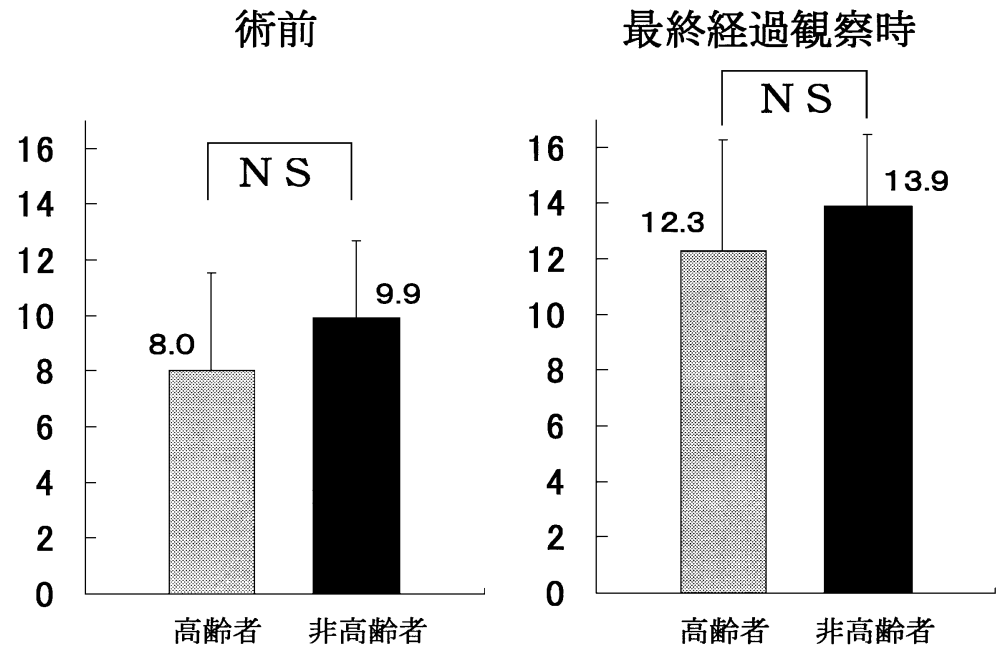

図 1 JOA score による術前及び最終経過観察時の両群の比較

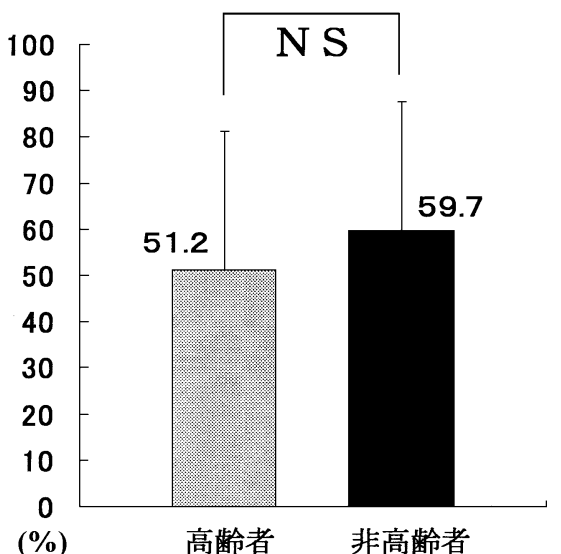

図 2 改善率の比較

高齢者が低い傾向にあるが統計学 的有意差は無い

のU検定を用いた。

結果

術前罹病期間は高齢者群 2 ケ月〜10 年（平均 19.8 ケ月), 非高齢者群 1 ケ月～10 年（平均 20.5 ケ月） で平均値としては差を認めなかった。手術時間は高齢 者群 120 分 251 分 (平均 174.8 分), 非高齢者群 121 分〜278 分（平均 191.2 分）であった. 出血量は高齢
者群 32g 1059g (平均 277.3g), 非高齢者群 $28 \mathrm{~g} \sim 1507 \mathrm{~g}$ （平均 333.5g） と統計学的には有意差は ないが高齢者に少ない傾向がみられた。

臨床成績はJOA scoreにより評価した。術前 JOA score は高齢者群 3 点 14 点 (平均 8 点), 非高齢者 群 4 点 13 点 (平均 9.9 点). 術後最終調査時の score は高齢者群 1 点 17 点 (平均 12.3 点), 非高齢 者群 8 点〜16 点（平均 13.9 点）であった（図 1 ）. いずれも高齢者で低かったが，有意差は出なかった． 改善率をみると高齢者群平均 $51.2 \%$, 非高齢者群 $59.7 \%$ となり有意差はなかったが高齢者に低い傾向が みられた（図 2 ).

次に JOA score を項目別に検討して上下肢運動機 能障害の推移を検討した。上肢機能は高齢者群 1.43 点から 3 点へ, 非高齢者群 1.8 点から 3.27 点へ, 改 善率はそれぞれ $61.1 \%$ と $68.8 \%$ であり有意差はなかっ た。 下肢機能においては高齢者群 1.19 点から 2.19 点 へ, 非高齢者群 2 点加ら 3.2 点, 改善率は $35.6 \%$ と 60 \%になり有意に高齢者群で下肢機能改善が劣っていた のが判明した（図 3 ).

術前合併症は高齢者 21 例中 15 例 $71.4 \%$ にみられ た. 特に高血圧が多く半数以上が合併していた．心疾 患も 1 例いたが，周術期に問題となるような心肺機能 の低下した患者はいなかった。非高齢者は $47 \%$ に合 併症がみられ糖尿病はむしろ非高齢者群で多かった 


\section{上肢 $\bullet$ 非高齢者 下 肢}
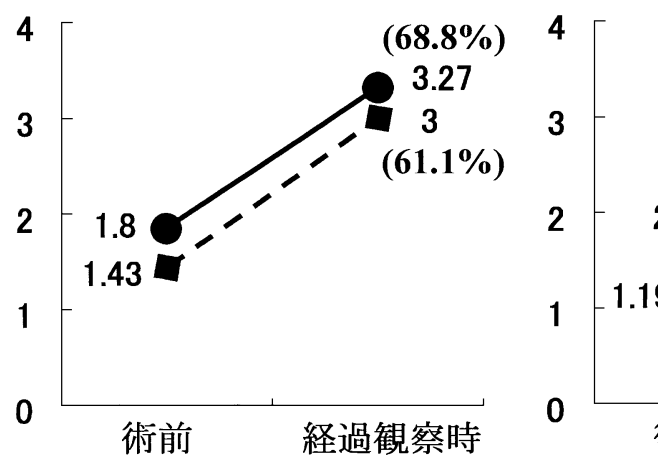

図 3 上下肢機能別にみた術前と経過観察時の JOA score の推移 （）内は改善率，下肢機能改善が有意に高齢者で劣っている.

表 1：術前合併症

\begin{tabular}{|c|c|c|}
\hline 疾患名 & 高齢者群 & 非高齢者群 \\
\hline 高血压 & 11 例（52.4\%） & 2 例 $(13.3 \%)$ \\
\hline 心疾患 & 3 例（14.3\%） & 2 例 (13.3\%) \\
\hline 糖尿病 & 1例（4.8\%） & 3 例 (20 \%) \\
\hline 喘息 & 1例（4.8\%） & 1 例 ( $6.7 \%)$ \\
\hline 脳梗塞 & 2 例（9.5\%） & 0 例 \\
\hline 肝障害 & 1 例（ $4.8 \% ）$ & 0 例 \\
\hline パーキンソン病 & 1 例（ $4.8 \%)$ & 0 例 \\
\hline 悪性腫瘍 & 1例（ $4.8 \%)$ & 1 例 ( $6.7 \%)$ \\
\hline
\end{tabular}

（表 1 ）.

術後合併症として一時的な夜間せん妄が両群で約 2 割の症例でみられた。このせん妄は全例数日で消失し たが，術前合併症のない人でも抢こっており，予測困 難であった．その他生命にかかわるような重篤な合併 症はみられなかった（表 2).

\section{考察}

高齢者の頚椎手術の症例の増加に伴い, 手術成績が 次第に明らかとなり, 頚髄症に限定すると JOA score 改善率はほぼ $40 \%$ ６0\% と報告されている．改善率 による治療成績の評価において，高齢者は非高齢者に

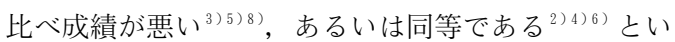
う各々の報告がある。高齢者の術後評価については JOA score だけでなく獲得点数やADLをも包括し
表 2 : 術後合併症

\begin{tabular}{l|ll}
\hline \hline \multicolumn{1}{c|}{ 疾患名 } & 高齢者群 & \multicolumn{1}{c}{ 非高齢者群 } \\
\hline 夜間せん妄 & 4 例 $(19.0 \%)$ & 3 例 $(20 \%)$ \\
頚肩腕痛 & 2 例 $(9.5 \%)$ & 1 例 $(6.7 \%)$ \\
創感染 & 2 例 $(9.5 \%)$ & 0 例 \\
薬剤性肝障害 & 0 例 & 1 例 $(6.7 \%)$ \\
尿路感染 & 1 例 $(4.8 \%)$ & 0 例 \\
\hline
\end{tabular}

て評価すべきとの意見もある ${ }^{17)}$ が，改善率以外の評 価法については統一したものはない，今回我々の検討 で得られた結果は，高齢者は非高齢者に比べ改善率は 低い傾向にあるものの統計学的有意差は無いこと, 改 善率が低い傾向があることの原因は主に下肢機能改善 が高齢者で有意に不良であることが成績低下の直接的 な原因となっていたこと，であったがこれはほぼ諸家 が指摘していた点と合致した結果であった。

我々の症例での高齢者下肢機能改善不良の原因とし て，1）脳梗塞の既往のあった 2 例では下肢機能の改 善が得られていない。2) 経過観察中 1 例が脳梗塞を 起こし歩行不能となった。 3 ) パーキンソン病の 1 例 はその為之思われる歩行障害が進行した，4）内科的 問題や意欲低下などにより室内に閉じこもりがちにな り歩行能力が低下した．5）变形性膝関節症や春柱管 狭窄症が術前から存在していたこと，などがあった。 また，術後一旦は回復した歩行機能が経過中に悪化し た症例が 3 割に及んで打り, 高齢者の手術効果を維持 
するためには下肢機能維持を目的としたリハビリや治 療, 生活指導などが必要と考えられた。

術前合併症は周術期に影響を及ぼしたものはなかっ たが，脳梗塞の既往があった症例では歩行能力の改善 は得られなかった，頚部脊䯣症はあるが合併症のため 手術を断念した症例も存在するが今回は検討していな い. 今後高齢者が増える状況の中で, ぞの程度の合併 症の存在まで手術適応とするのかは今後の検討課題と 考える.

術後合併症での最多の問題は夜間せん妄であり非高 齢者でむ発生していたが，今回術前合併症のなかった 症例であ発生しており術前に予想は困難であった。そ の他生命予後に問題となった合併症は発生していない. 高齢者でも比較的良好な成績が得られる場合む多い ので, 進行性の神経障害があり ADL の改善を希望す る症例では, 下肢機能改善不良を来す合併症の存在に 注意して手術治療を積極的に考慮し，また手術した場 合には下肢機能維持を目的とした術後の生活指導や治 療を行うべきと考える.

\section{ま と め}

1) 頚部脊䯣症に対して脊柱管拡大術を施行した 70 歳以上の高齢者群を 69 歳以下の群と比較検討した. 2 ) 高齢者群は非高齢者群に比較して改善率は劣るが, 比較的良好な成績が得られていた。
3) 高齢者群は下肢運動機能改善が非高齢者群に比較 して有意に劣って抢り約 30\%の症例で経過中に歩 行能力の低下がみられた。

4 ) 術前合併症は高齢者群に多かった。術後は一過性 の夜間せん妄が両群で $20 \%$ 症例にみられた。生 命予後にかかわる大きな合併症はなかった。

\section{参 考 文 献}

1）林 協司ら：高齢の頝椎症性脊䯣症手術患者の転帰に ついて. 西日本脊椎研究会誌, $27: 61-64,2001$.

2）池田天史万：高齢者の䅡椎症性脊䯣症に対する脊柱管 拡大術の成績. 西日本脊椎研究会誌, $27: 95-97,2001$.

3）小西宏昭, 原真一郎, 鳥越雄喜：70歳以上の頝部春䯣 症の特徴之問題点. 別冊整形外科, $29: 176-179,1996$.

4）宮里剛成ら：高齢者䅡椎症性脊䯣症に対する後方除圧 術の検討一青壮年者との対比. 西日本脊椎研究会誌, 27 ： 103-106, 2001.

5）三好光太弓：高齢者に打ける䁈椎症性脊䯣症に対する 脊柱管拡大術。春椎脊䯣, $12:$ 995-999, 1999.

6）大和田哲雄：高齢者の頝䯣症一その病態之手術成績. NEW MOOK 整形外科, 6:223-229. 越智隆弘編, 東 京，金原出版，1999.

7）田中雅人, 甲斐信生，中原進之介：高齢者（70 歳以上） の頚椎疾患の手術例の検討. 西日本脊椎研究会誌, 27 ： 65-66, 2001.

8）内田研造ら：高齢者における頝椎症性脊䯣症の手術適 応. 春椎脊䯣, $12: 985-988,1999$. 